\title{
Effect of Additional Fiberglass Fiber on Concrete Performance
}

\author{
Subandi ${ }^{*}$, Santi Yatnikasari, Mukhripah Damaiyanti, Rafidah Azzahra, Vebrian \\ Universitas Muhammadiyah Kalimantan Timur, Jl.Ir.Juanda No.51, Samarinda, Kalimantan Timur 75124, Indonesia
}

Corresponding Author Email: 17111024430022@umkt.ac.id

https://doi.org/10.18280/acsm.430502

Received: 9 August 2019

Accepted: 12 September 2019

\section{Keywords:}

fiberglass concrete, fibrous, fiber, chopped strand mat, material

\begin{abstract}
As the progress of using materials for making concrete is growing, a lot of research has been done to make concrete with a variety of materials to get concrete performing well. The compressive strength and split concrete are influenced by what materials are used. This study conducted an experiment to make fibrous concrete using a mixture of fiberglass material type Chopped Strand Mat (CSM), CSM was cut to a size of $1 \mathrm{~cm} \mathrm{x} 4 \mathrm{~cm}$ then CSM was described by pulling CSM from the webbing. The cylindrical specimens measuring $150 \mathrm{~mm}$ x $300 \mathrm{~mm}$, the compressive strength of the plan $20 \mathrm{Mpa}$ with 4 kinds of mixed variations of $0 \%, 0.25 \%$, $0.5 \%$, and $0.75 \%$ of the weight of cement used. Compressive and split strength testing of concrete aged 7, 14, and 28 days. The results of slump test results showed that the greater the percentage of Fiberglass the lower the slump produced. The compressive strength test results obtained $0 \%$ at the age of 28 days obtained compressive strength of $20.2 \mathrm{MPa}$, while the highest addition of fiberglass compressive strength at 28 days the addition of fiberglass by $0.25 \% 24.6 \mathrm{MPa}$. The highest tensile strength at $0.75 \%$ fiber addition was $3.9 \mathrm{MPa}$, and the maximum flexural strength at $0.75 \%$ fiber addition was $2.889 \mathrm{MPa}$. From the results of this study it was concluded that with the addition of $0.25 \%$ fiberglass it was found to be strong the highest compressive strength is $24.6 \mathrm{MPa}$ and the splitting strength of $3.9 \mathrm{MPa}$ is produced from the addition of $0.75 \%$ fiber, and the flexural strength of $2.889 \mathrm{MPa}$ is produced from the addition of $0.075 \%$ fiber. with the addition of a certain percentage of fiberglass can add compressive strength, tensile strength and flexural strength in concrete.
\end{abstract}

\section{INTRODUCTION}

The concept of using fibers as reinforcement is not new. Fibers have been used as reinforcement since ancient times. Historically, horsehair was used in mortar and straw in mudbricks. In the 1900s, asbestos fibers were used in concrete. In the $1950 \mathrm{~s}$, the concept of composite materials came into being and fiber-reinforced concrete was one of the topics of interest. Once the health risks associated with asbestos were discovered, there was a need to find a replacement for the substance in concrete and other building materials. By the 1960s, steel, glass (GFRC), and synthetic (such as polypropylene) fibers were used in concrete. Research into new fiber-reinforced concretes continues today. Fiberreinforced concrete (FRC) is concrete containing fibrous material which increases its structural integrity. It contains short discrete fibers that are uniformly distributed and randomly oriented. Fibers include steel fibers, glass fibers, synthetic fibers and natural fibers - each of which lends varying properties to the concrete. In addition, the character of fiber-reinforced concrete changes with varying concretes, fiber materials, geometries, distribution, orientation, and densities [1]. ASTM said [2] glass fibers fall into two categories, low cost versatile and versatile fiber. More than $90 \%$ of all glass fibers are general- destination products. This fiber is known by the designation of E-glass and subject to ASTM Specifications. The remaining glass fiber is a premium special-purpose product. Many, like E-glass, have a letter designation implies the special properties of glass fiber trade names, but not all are subject t,o ASTM specification.
Specifically see Figure 1.

\begin{tabular}{|ll|}
\hline Letter designation & \multicolumn{1}{c|}{ Property or characteristic } \\
\hline E, electrical & Low electrical conductivity \\
S, strength & High strength \\
C, chemical & High chemical durability \\
M, modulus & High stiffness \\
A, alkali & High alkali or soda lime glass \\
D, dielectric & Low dielectric constant \\
\hline
\end{tabular}

Figure 1. Glass fiber types

The concept of using fiber as a reinforcement of freedom of new things. Fiber has been used as reinforcement since ancient times. Historically, horsehair was used in mortars and straw in mud bricks. In the 1900s, asbestos fibers were used in concrete. In the 1950s, the concept of composite materials emerged and concrete that collected fiber was one of the interesting topics. Once the health risks associated with asbestos are discovered, there is a need to find fuel in concrete and other building materials. In the 1960s, steel, glass (GFRC), and synthetic fibers (such as polypropylene) were used in concrete. Research into new concrete approved fibers continues to this day. Fiberreinforced concrete (FRC) is concrete containing fibrous material that increases its structural integrity. It contains short discrete fibers that are uniformly distributed and randomly oriented. Fibers include steel fibers, glass fibers, synthetic fibers, and natural fibers - each giving a different property to concrete. In addition, the character of fiber reinforced concrete 
changes with diverse concrete, fiber material, geometry, distribution, integrated, and solid.

Fibrous concrete has begun to be widely used along with the development of mixed materials in the manufacture of concrete that has various purposes for its use, various types of fibers used such as steel fibers, plastics, fabrics and so forth.

In this study, the fiber that we use is fiber from fiberglass. Fiberglass (US) or fiberglass (UK) is a common type of fiber- reinforced plastic using glass fiber. The fibers may be randomly arranged, flattened into a sheet (called a chopped strand mat), or woven into a fabric. The plastic matrix may be a thermoset polymer matrix-most often based on thermosetting polymers such as epoxy, polyester resin, or vinyl ester-or a thermoplastic [3]. Several types of fibers commonly used in the manufacture of fibrous concrete, see Figure 2.

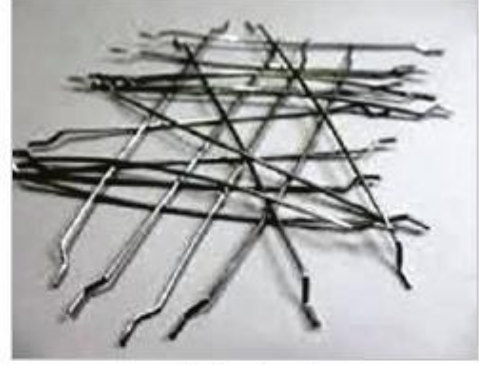

Hooked-end

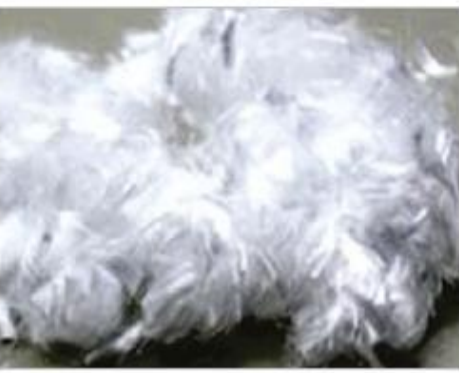

Polypropylene

\section{Steel fibers}

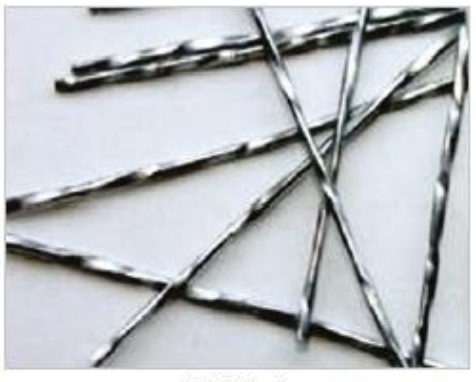

Twisted

Synthetic fibers

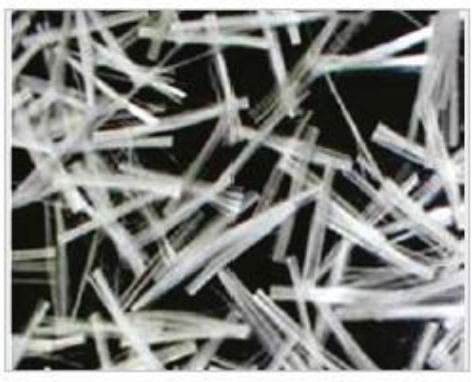

Glass

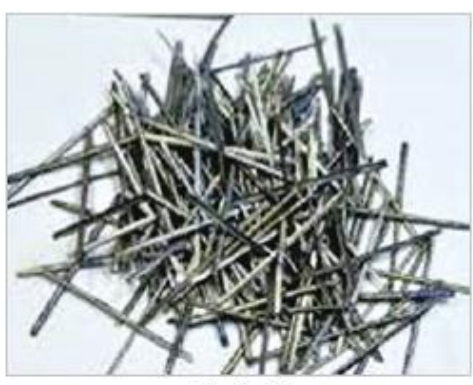

Straight

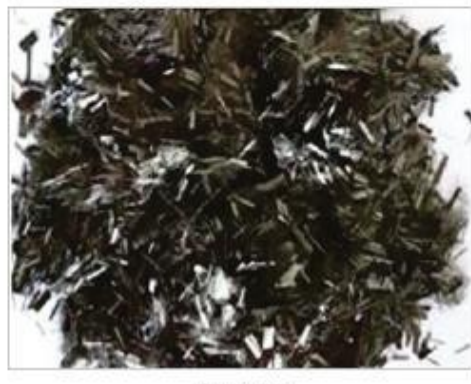

Carbon

Figure 2. Types of fiber

Cheaper and more flexible than carbon fiber, it is stronger than many metals by weight, is non-magnetic, non-conductive, transparent to electromagnetic radiation, can be molded into complex shapes, and is chemically inert under any circumstances. Applications include aircraft, boats, automobiles, bathtubs and enclosures, swimming pools, hot tubs, septic tanks, water tanks, roofing, pipes, cladding, orthopedic casts, surfboards, and external door skins. Fiberglass covers are also widely used in the water treatment industry to help control odors [4].

In the design of concrete structures, tensile stress that occurs is retained by reinforcing steel, whereas tensile concrete is not taken into account withstand the tensile, that occur because concrete will immediately crack if it gets tensile stress that goes beyond tensile strength. In terms of structural durability, these cracks will corrode steel reinforcement so that it will reduce the area of steel reinforcement, although from the view of this crack structure is not dangerous. One way to reduce cracks in the tensile area is to add fiber-added material. Principle fiber addition itself gives reinforcement to the concrete which is spread evenly into the concrete mix with orientation random to prevent concrete cracks that are too early in the tensile area due to heat or hydration due to loading. So that the tensile strength of fiber concrete can be higher than the tensile strength of concrete ordinary.

The strength of concrete is influenced by the materials used, various methods have been carried out to make concrete perform better, the use of rice husk ash and fly ash to make high quality concrete has been able to have an impact on the use of both materials. without the use of these two materials [5], utilization of materials derived from waste, such as concrete using sand from husk charcoal [6-7], utilizing ironwood waste for structural light aggregate [8], the use of ironwood and husk charcoal rice in making lightweight concrete to replace coarse aggregate and sand [9].

Recent studies performed on a high-performance fiberreinforced concrete in a bridge deck found that adding fibers provided residual strength and controlled cracking [10] There were fewer and narrower cracks in the FRC even though the FRC had more shrinkage than the control. Residual strength is directly proportional to the fiber content. Research into systematic design methodologies for producing selfcompressed concrete (SFRSCC) consisting of steel fiber reinforcements. This is intended to achieve concrete that can consolidate itself which can produce multiple benefits from the property which consolidates itself and also the toughness of the composite. Experimental modeling consists of designing a mortar phase using producing sand (M-sand) as a fine aggregate using a systematic mixed design methodology based on the concept of particle packaging. Optimization of aggregates arrived based on the concept of packing density by conducting a slump cone study. The powder combination consisting of cement and granite blast furnace slag (GGBFS) was selected by conducting a paste consistency test. Finally, the superplasticizer dose was determined based on the Marsh cone study and the steel fiber volume fraction from the slump 
flow study. The workability of standard concrete and high strength is affected by the inclusion of steel fiber dosage and fresh properties reveal the importance of maintaining high paste volume for better flow capability. Based on the proposed mixed design methodology with M-sand, high strength selfcompacting concrete is achieved up to $70 \mathrm{MPa}$. Experimental investigations are reported on other assessments made of the fresh and hardened properties of self-compacting steel fiber concrete mixtures [11]. The fabrication and optimization of the occupancy layer is very important for the performance of protective work. The new protective layer made of high quality concrete reinforced by steel fibers (SFRHSC) is far more profitable than ordinary concrete [12].

A carpet typically consists of two layers of backing (usual fabric from polypropylene tape yarns), joined by $\mathrm{CaCO} 3$ filled styrene-butadiene latex rubber (SBR), and face fibers (the majority being nylon 6 and nylon 66 textured yarns). Such nylon and polypropylene fibers can be used for concrete reinforcement. Other ideas are emerging to use recycled materials as fibers: recycled Polyethylene terephthalate (PET) fiber, for example [13].

Research on the use of fibrous concrete is able to reduce reinforcing steel in concrete. the fine steel fiber enhanced the compressive properties of samples, which showed clear plastic deformation [14]. In the market fiber for concrete admixtures has been produced, one of them is Bon 32-500 which is made by the American company BON [15].

The research uses several types of fiber, among others Fibers, include steel fibers, glass fibers, synthetic fibers and natural fibers This study presents understanding strength of fiber reinforced concrete [16], Polypropylene fibers enhance the strength of concrete, without causing the well-known problems, normally associated with steel fibers [17]

In this study to determine the compressive strength and flexural strength of concrete using materials from fiberglass with a mixture of fiberglass fibers to cement weight of $0 \%$, $0.25 \%, 0.5 \%$, and $0.75 \%$, compressive strength, tensile strength testing and splitting the test specimens were carried out on specimens aged 7, 14 and 28 days. The use of materials takes into account the standards of Fiber for Concrete [18], Test methods for fibers in concrete [19], Standard specifications for steel fibers for fiber-reinforced concrete [20], and Standard Test Methods for Flexural Toughness and FirstCrack Strength of Fiber - Reinforced Concrete [21].

Pure Flexural Capacity, Pure Flexural Strength is the flexing that occurs in a beam by conditioning the latitude force equal to zero. To estimate the bending moment capacity, fiber concrete can be considered as a composite material consisting of concrete and a small portion of fiber, see Figure 3.

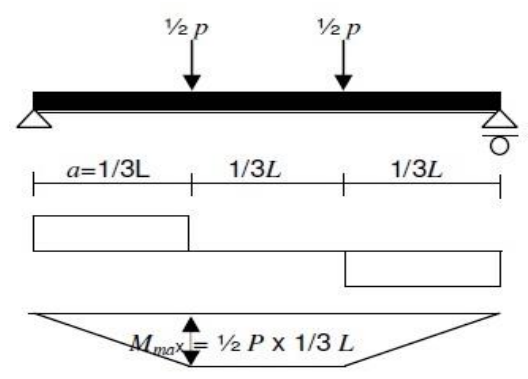

Figure 3. Beam bending test

Flexural strength in beams can be determined using Equation (1).

$$
\mathrm{M}_{\max }=1 / 2 \mathrm{P} \times 1 / 3 \mathrm{~L}
$$

Information:

$\mathrm{M}$ max : maximum moment

$\mathrm{P} \quad$ : load cell load

L : beam span

\section{MATERIAL AND METHOD}

The research starts from preparing fiberglass fibers $2-4 \mathrm{~cm}$ long and making concrete blocks and concrete cylinders in four fiber compositions to the concrete volume

Each of the nine concrete cylinders and three blocks measuring $15 \mathrm{~cm} \times 20 \mathrm{~cm} \times 110 \mathrm{~cm}$ to test the optimum flexural strength of fiberglass.

The materials used in this study are coarse aggregates, fine aggregates, PCC type cement, fiberglass fibers, and water.

\subsection{Fiberglass material}

The fiber material used is a CSM fiberglass material, the fiberglass is cut into pieces with a size of $1 \mathrm{~cm} \mathrm{x} 4 \mathrm{~cm}$, then the pieces of fiberglass fibers are broken down by pulling it apart from the woven fiber.

\subsection{Material testing}

Material testing is carried out on coarse and fine aggregate materials including specific gravity, fill weight, absorption, gradation and sludge content. Testing of coarse aggregate, and fine aggregate, using SNI and ASTM methods [22-26].

\subsection{Mix design}

Mix design in this study, using Indonesian National standards

\subsection{Test object}

The test object to be used is a cylindrical test object with a diameter of $15 \mathrm{~cm} \times 30 \mathrm{~cm}$, in accordance with Indonesian national standards.

\subsection{Compressive strength testing}

Compressive strength testing of the test specimens is carried out for specimens at the age of, 7 days, 14 days and 28 days. Procedure for compressive strength testing using the method [27].

\section{RESULTS AND DISCUSSION}

In this chapter describes the results that have been made from the manufacture of ironwood aggregate material, material testing, slump testing, test specimen manufacture, compressive strength testing, and discussion of the results of research

\subsection{Material testing results}

Material test results are shown in Table 1. 
Table 1. Material testing results

\begin{tabular}{cccc}
\hline NO & Material & Coarse Aggregate & Sand \\
\hline $\mathbf{1}$ & Solid fill weight & $1.485,90$ & 1631,29 \\
\hline $\mathbf{2}$ & Crumbly fill weight & $1.408,30$ & $1.476,61$ \\
\hline $\mathbf{3}$ & Specific gravity & 2,51 & 2,473 \\
\hline $\mathbf{4}$ & Water Absorption & 2,04 & 0.012 \\
\hline $\mathbf{5}$ & Fine-grain modulus & 7,67 & 3.16 \\
\hline $\mathbf{6}$ & Abrasion & 32,826 & - \\
\hline $\mathbf{7}$ & Organic matter & - & 1 \\
\hline $\mathbf{8}$ & Sludge content & 1,58 & 0,31 \\
\hline
\end{tabular}

\subsection{Mix design results}

The results of the mix design are shown in Table 2 .

Table 2. Mix design

\begin{tabular}{cccc}
\hline $\begin{array}{c}\text { Water } \\
(\mathbf{k g})\end{array}$ & $\begin{array}{c}\text { Semen } \\
(\mathbf{k g})\end{array}$ & $\begin{array}{c}\text { Fine Aggregate } \\
(\mathbf{k g})\end{array}$ & $\begin{array}{c}\text { Coarse Aggregate } \\
(\mathbf{k g})\end{array}$ \\
\hline 185 & 321 & 791,9 & 979,2 \\
\hline
\end{tabular}

Table 2 shows the results of the mix design, the addition of fiberglass is adjusted to the number of presentations of each variation.

\subsection{Slump test results}

From the results of the test without fiber concrete produces an $80 \mathrm{~mm}$ slump, the more fiber additions the smaller the slump obtained.

\subsection{Compressive strength}

Compressive strength of specimens carried out on concrete age 7 days, 14 days, and 28 days each concrete age tested by 3 pieces with a Digital Compression Machine, from the results of this test can be obtained concrete weight $/ \mathrm{m}^{3}$ and compressive strength concrete $(\mathrm{MPa})$. The results of the concrete compressive strength test are shown in Table 3.

Table 3. Compressive strength test results

\begin{tabular}{ccccc}
\hline $\begin{array}{c}\text { The test object's } \\
\text { age (days) }\end{array}$ & $\mathbf{0} \%$ & $\mathbf{0 , 2 5 \%}$ & $\mathbf{0 , 5 \%}$ & $\mathbf{0 , 7 5 \%}$ \\
\hline 7 & 14,9 & 16,3 & 12,22 & 12,12 \\
\hline 14 & 17,4 & 21,2 & 16,32 & 15,25 \\
\hline 28 & 20,36 & 24,21 & 19,65 & 18,01 \\
\hline
\end{tabular}

Table 3 menunjukan hasil dari pengujian kuat tekan beton menggunakan serat fiberglass.

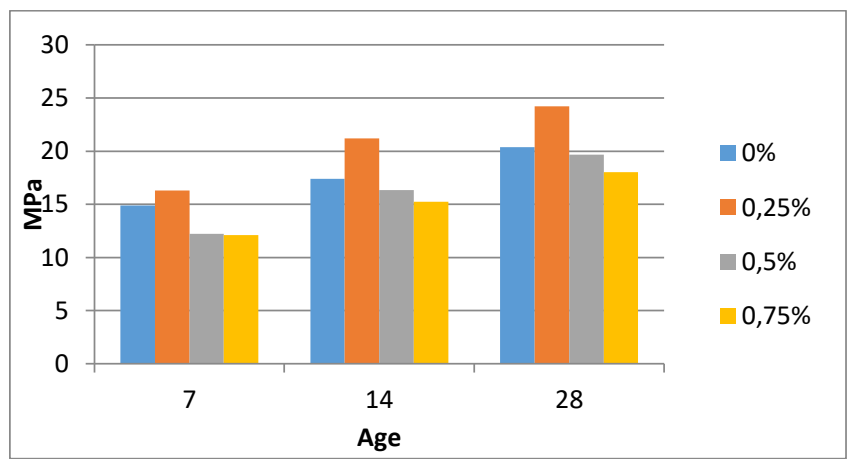

Figure 4. Development of concrete compressive strength

\subsection{Split tensile strength testing}

The results of the tensile testing of the test pieces are presented in Table 4.

Table 4. Split tensile test results

\begin{tabular}{cc}
\hline Fiber Levels (\%) & MPa \\
\hline 0 & 2,7 \\
\hline 0,25 & 3,2 \\
\hline 0,5 & 3,5 \\
\hline 0,75 & 3,9 \\
\hline
\end{tabular}

Table 4 is the result of split tensile testing, the more fiberglass content the higher the strength produced.

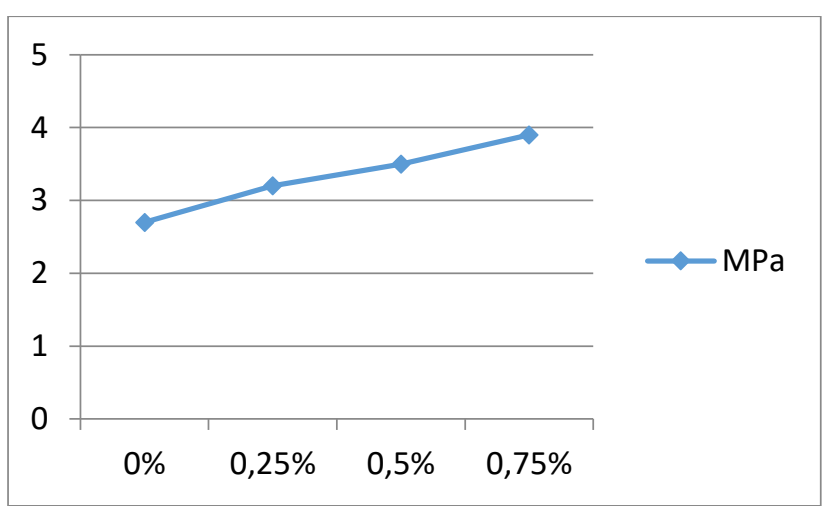

Figure 5. Development of split tensile test specimens

\subsection{Beam bending test}

Beam flexural test results are presented in Table 5.

Table 5. Beam flexural test results

\begin{tabular}{ccc}
\hline Fiber Levels (\%) & Load & MPa \\
\hline 0 & 2100 & 2,333 \\
\hline 0,25 & 2175 & 2,416 \\
\hline 0,5 & 2250 & 2,500 \\
\hline 0,75 & 2600 & 2,889 \\
\hline
\end{tabular}

\subsection{Discussion}

\subsubsection{Compressive strength}

The results showed that the compressive strength value of normal concrete ( $0 \%$ fiber content) was $20.36 \mathrm{MPa}$, fiberglass fiber concrete with fiber content $0.25 \%$ compressive strength of $24.21 \mathrm{MPa}, 0.5 \%$ fiber concrete compressive strength of 19.65 MPa, $0.75 \%$ fiber concrete compressive strength of 18.01 MPa and fiber concrete. The addition of fiberglass by $0.25 \%$; has a higher strength compared to specimens without fiber, while $0.5 \%$; $0.75 \%$ of the concrete volume results in lower compressive strength compared to normal concrete (0\%). The best compressive strength value produced by fiberglass fiber concrete with a fiber content of $0.25 \%$ of the volume of concrete, thus indicating that the fiber content of $0.25 \%$ is the optimum fiber content value that can be added to the concrete mix due to the addition of fiber with optimum levels of fiber filling almost all existing cavities and with not excessive fiber content, the mixture does not lack the binding material (cement paste) that binds the fiber so that it does not cause a reduction in adhesion which can cause friction and 
bonding between the concrete stacking material after hardening.

\subsubsection{Modulus of concrete elasticity}

From the testing of concrete elastic modulus, it is found that the addition of fiberglass will increase the concrete elastic modulus. But with the amount of fiber added the higher it causes an increase in the modulus of elasticity of the concrete so that the amount of fiber content added to the concrete mix causes the strain that occurs in the concrete will also be even greater. As we know, the modulus of elasticity is the value of the ratio between stress and strain under elastic conditions.

Ductility The highest split tensile strength occurs in fiber concrete with the addition of $0.75 \%$ fiber, and the tensile strength of concrete will increase with the addition of fiberglass fibers, but the tensile strength of concrete is still above the tensile strength of normal concrete. The test results show the tensile stress for normal concrete is $2.7 \mathrm{MPa}$, fiberglass fiber concrete with a fiber content of $0.25 \%$ of the volume of concrete produces tensile strength of $3.2 \mathrm{MPa}$, fiber concrete with a fiber content of $0.5 \%$ tensile strength of 3.5 $\mathrm{MPa}$, for a fiber content of $0.75 \%$ the tensile strength is 3.9 $\mathrm{MPa}$ so the addition of fiberglass to the concrete mix can increase the tensile strength of concrete.

\subsubsection{Beam bending test}

Based on Table 5, it can be seen that the flexural strength test results in this study amounted to $2.688 \mathrm{MPa}$. This flexural strength value is caused by the addition of fiberglass which is spread evenly when mixing concrete so that the bond between the aggregate and cement paste becomes larger so that the initial cracks during loading can be inhibited by the fiber. The more levels of fiberglass, the greater the flexural strength produced.

\section{CONCLUSIONS}

Based on the results and discussion above, it can be concluded:

(1) The addition of $0.25 \%$ fiberglass for compressive strength of concrete results in better compressive strength when compared to concrete without fiber and other fiber content where the addition of $0.25 \%$ fiber produces a compressive strength of $24.21 \mathrm{MPa}$, while the addition of fiberglass at other levels decreased strength.

(2) For the addition of fiber in the tensile pull of the concrete the opposite occurs, the greater the fiber content, the greater the strength obtained, the greatest strength of the tensile pull with a content of $0.75 \%$ of $3.9 \mathrm{MPa}$. While the content of other fibers experiences more strength than concrete without fiber $(0 \%)$.

(3) The flexural strength is in line with the results obtained in the tensile division where the greater the additional fiberglass fibers the greater the strength produced. The greatest strength in the addition of $0.75 \%$ fiber is $2,889 \mathrm{MPa}$, while the addition of other fibers is higher than concrete without using fiber $(0 \%)$.

(4) The addition of fiberglass to a certain degree can increase the compressive strength, split tensile and melt strength of concrete.

\section{ACKNOWLEDGMENT}

Thanks to Professor DR. Bambang Setiaji as Rector of Universitas Muhammadiyah Kalimantan Timur, Ghozali, Ph.D. as Affairs of Academic, Sunarso, SE., MM as Affairs of Students, and Ir. Waluyo Adi Siswanto, M.Eng., Ph.D. as Dean of Faculty Sains and Technology who have guided and support in this research.

\section{REFERENCES}

[1] Fiber-Reinforced Concrete Title, Wikipedia. https://en.wikipedia.org/wiki/Fiber-reinforced_concrete, accessed on Aug. 8, 2019.

[2] R.H.O. (1943). Glass fiber. Journal of the Franklin Institute, 236(1): 80. https://doi.org/10.1016/S00160032(43)91201-3

[3] Fiberglass. https://en.wikipedia.org/wiki/Fiberglas, accessed on Aug. 8, 2019.

[4] Structural analysis of GRP tank covers. Coventive Composites.

[5] Lam, T.V., Bulgakov, B., Aleksandrova, O., Larsen, O., Ngoc Anh, P. (2018). Effect of rice husk ash and fly ash on the compressive strength of high performance concrete. E3S Web of Conferences, p. 02030. https://doi.org/10.1051/e3sconf/20183302030

[6] Subandi, Nasrulah, T., Arha, A.A., Zulkarnain, I., Asnan, M.N. (2019). Effect of addition of rice husk charcoal on concrete compressive strength. International Journal of Engineering and Advanced Technology, 8(6): 4951-4955. https://doi.org/10.35940/ijeat.F9251.088619

[7] Subandi, Kusuma, C., Asnan, M.N., Damaiyanti, M., Yatnikasari, S. (2019). Manufacture of concrete with artificial sand from rice husk waste. International Journal of Recent Technology and Engineering, 8(3): 1670-1673. https://doi.org/10.35940/ijrte.C4438.098319

[8] Subandi, Cahyono, R.H., Kusuma, C., Asnan, M.N. (2019). Artificial aggregate lightweight structural. Annales de Chimie - Science des Matériaux, 43(4): 213216. https://doi.org/10.18280/acsm.430403

[9] Subandi, Arha, A.A., Kusuma, C., Asnan, M.N. (2019). Utilization of ironwood waste and husk charcoal to produce lightweight concrete. International Journal of Civil Engineering, 6(7): 17-22. https://doi.org/10.14445/23488352/IJCE-V6I7P104

[10] Fiber Reinforced Concrete - Types, Properties and Advantages. https://theconstructor.org/concrete/fiberreinforced-concrete/150/, accessed on Aug. 15, 2019.

[11] Basheerudeen, A., Anandan, S. (2015). Simplified mix design procedures for steel fibre reinforced self compacting concrete. Engineering Journal, 19(1): 21-36. https://doi.org/10.4186/ej.2015.19.1.21

[12] Li, J., Shi, S., He, H., Chen, S. (2019). Split-hopkinson pressure bar test and numerical simulation of steel fiberreinforced high-strength concrete. Revue des Composites et des Matériaux Avancés, 29(2): 109-117. https://doi.org/10.18280/rcma.290206

[13] Ochi, T., Okubo, S., Fukui, K. (2007). Development of recycled $\mathrm{PET}$ fiber and its application as concretereinforcing fiber. Cement and Concrete Composites, 29(6): 448-455. https://doi.org/10.1016/J.CEMCONCOMP.2007.02.002

[14] Zhu, J., Zheng, W., Sneed, L., Huang, Y., Xu, C. (2019). 
Mechanical properties of plant fibers reinforced Alkaliactivated slag cementitious material at high temperature. Annales de Chimie - Science des Matériaux, 43(4): 249255. https://doi.org/10.18280/acsm.430408

[15] Bon 32-500 1 Pound Bag 3/4-Inch Anti-Crak Concrete Fibers - Fiberglass Concrete Additive - Amazon.com. https://www.amazon.com/32-500-4-Inch-Anti-CrakConcrete-Fibers/dp/B000CODWAE. accessed on Aug. 15, 2019.

[16] Ragavendra, S., Reddy, I.P., Dongre, A. (2017). Fibre reinforced concrete-a case study. Conference Paper, pp. $1-15$.

[17] Madhavi, T.C., Reddy, M., Kumar, P., Raju, S., Mathur, D. (2015). Behaviour of polypropylene fiber reinforced concrete. International Journal of Applied Engineering Research, 10(9): 22627-22638.

[18] European, S. (2006). Test methods for fibres in concrete - Part 2: Effect on concrete. In Test Methods for Fibres in Concrete - Part 2: Effect on Concrete.

[19] British Standards Institution. Test methods for fibres in concrete. Part 2, Effect on concrete.

[20] ASTM A820/A820M-16 Standard specification for steel fibres for fibre-reinforced concrete, American Society for Testing and Materials - Publication Index | NBS. https:/www.thenbs.com/PublicationIndex/documents/d etails?Pub=ASTM\&DocID=320777, accessed on Aug. 20, 2019.

[21] ASTM C1018 - 97 Standard Test Method for Flexural
Toughness and First-Crack Strength of Fiber-Reinforced Concrete (Using Beam With Third-Point Loading) (Withdrawn 2006). https://www.astm.org/Standards/C1018.htm, accessed on Aug. 20, 2019.

[22] SNI 03-1970-1990. (1990). Metode Pengujian Berat Jenis dan penyerapan air agregat halus, Bandung: Badan Standardisasi Indonesia, pp. 1-17.

[23] Astm, S.N.I. (2012). Metode uji untuk analisis saringan agregat halus dan agregat kasar ( ASTM C 136-06, IDT).

[24] ASTM C127 - 15, ASTM C127 - 15 Standard Test Method for Relative Density (Specific Gravity) and Absorption of Coarse Aggregate. https://www.astm.org/Standards/C127, ccessed on Jul. 30, 2019.

[25] ASTM C136 / C136M, ASTM C136 / C136M - 14 Standard Test Method for Sieve Analysis of Fine and Coarse Aggregates. https://www.astm.org/Standards/C136, accessed on Jul. $30,2019$.

[26] SNI 03-4804-1998. (1998). Metode Pengujian Bobot Isi dan Rongga Udara dalam Agregat, Balitbang PU, pp. 16.

[27] ASTM-C39/C39M-18, ASTM C39 / C39M - 18 Standard Test Method for Compressive Strength of Cylindrical Concrete Specimens. https://www.astm.org/Standards/C39, accessed on July $30,2019$. 